\title{
Renal double negative T cells: increasing importance in health and disease
}

\author{
Mohanraj Sadasivam ${ }^{1}$, Sanjeev Noel ${ }^{2}$, Hamid Rabb $^{2}$, Abdel Rahim A. Hamad ${ }^{1}$ \\ ${ }^{1}$ Department of Pathology, ${ }^{2}$ Division of Nephrology, Johns Hopkins University School of Medicine, Baltimore, MD, USA \\ Correspondence to: Hamid Rabb. Division of Nephrology, Johns Hopkins University School of Medicine, 720 Rutland Avenue, Ross 965, Baltimore, \\ MD 21205, USA. Email: hrabb1@jhmi.edu. \\ Provenance: This is an invited article commissioned by the Section Editor Dr. Cheng Yuan (Zhongnan Hospital, Wuhan University, China). \\ Response to: Nemenoff RA, Kleczko EK, Hopp K. Renal double negative T cells: unconventional cells in search of a function. Ann Transl Med \\ 2019;7:S342.
}

Submitted Oct 18, 2019. Accepted for publication Nov 05, 2019.

doi: $10.21037 / \mathrm{atm} .2019 .11 .51$

View this article at: http://dx.doi.org/10.21037/atm.2019.11.51

We thank the authors for the in-depth commentary on our recently published manuscript "Activation and Proliferation of PD-1+ Kidney Double-Negative T Cells Is Dependent on Nonclassical MHC Proteins and IL-2" (1). The authors have very nicely reviewed the historic aspects, key publications and challenges in studying kidney TCR $\alpha \beta$ double negative (DN) T cells. We particularly appreciate how balanced and rigorous it was. We concur that our understanding of DN T cells is severely lagging behind that of other lymphocyte lineages. A main reason is the lack of surface markers that specifically identify DN T cells, which is necessary to replace current approaches that use exclusion to identify DN T cells. We agree with their point that the best current markers to identify DNT cells is a combination of expression and absence of select surface molecules leading to the profile of CD45+TCR $\alpha \beta+C D 1 d-C D 4-C D 8-(2)$. As stated in their commentary, discrepancies in DN T cell frequency in different publications may be due to different gating strategies and different methods of tissue processing.

Similar to our original findings Nemenoff et al., were able to detect the PD-1+ subset of kidney DNT cells in B6 mice. However, their frequency is lower than we detected in younger, 8-10 weeks old mice. Another possible difference was that we included $\mathrm{CD} 45^{\text {int }} \mathrm{TCR}^{\text {int }}$ lymphocytes while gating. Tight gating by Nemenoff et al., might have also contributed to detection of fewer PD-1+ DNT cells. Analysis of kidney DN T cells in ADPCKD models is novel. Perhaps future functional studies of the DN T cells in these setting may reveal important changes in normal and diseased kidneys that were not seen during simple analysis of absolute numbers and frequencies.

\section{Acknowledgments}

None.

\section{Footnote}

Conflicts of Interest: The authors have no conflicts of interest to declare.

Ethical Statement: The authors are accountable for all aspects of the work in ensuring that questions related to the accuracy or integrity of any part of the work are appropriately investigated and resolved.

\section{References}

1. Sadasivam M, Noel S, Lee SA, et al. Activation and Proliferation of PD-1(+) Kidney Double-Negative T Cells Is Dependent on Nonclassical MHC Proteins and IL-2.J Am Soc Nephrol 2019;30:277-92.

2. Nemenoff RA, Kleczko EK, Hopp K. Renal double negative T cells: unconventional cells in search of a function. Ann Transl Med 2019;7:S342.

Cite this article as: Sadasivam M, Noel S, Rabb H, Hamad ARA. Renal double negative $\mathrm{T}$ cells: increasing importance in health and disease. Ann Transl Med 2020;8(4):143. doi: 10.21037/atm.2019.11.51 